\title{
The Edible Mushroom Pleurotus spp.: I. Biodiversity and Nutritional Values
}

\author{
Parisa Maftoun ${ }^{1}$, Helmi Johari ${ }^{1}$, Mohammad Soltani ${ }^{1}$, Roslinda Malik ${ }^{1}$, Nor Zalina Othman ${ }^{1}$ \\ and Hesham A. El Enshasy ${ }^{1,2, *}$
}

${ }^{1}$ Institute of Bioproduct Development (IBD), Universiti Teknologi Malaysia (UTM), Skudai, Johor Bahru, Johor, Malaysia

${ }^{2}$ Genetic Engineering and Biotechnology Research Institute (GEBRI), City for Scientific Research and Technology Applications, New Burg Al Arab, Alexandria, Egypt

\begin{abstract}
Mushrooms are macrofungi with numerous varieties and widely known as food and medicine in many ancient cultures. They are considered as potential source of many essential nutrients as well as therapeutic bioactive compounds and thus became one of the main components in Traditional Chinese Medicine (TCM) and in Japanese herbal medicine since more than two thousand years. The genus Pleurotus (widely known as oyster mushroom) is fast growing fungus belongs to basidiomycota group and considered as one of the famous species with many health benefits. Nowadays, seventy species of this genus has been discovered, but solely a few of them such as $P$. florida, $P$. sajor-caju and $P$. ostreatus are available in the market. The rich nutrients such as proteins, fibers, carbohydrates, minerals, vitamins, and lipids present this mushroom as famous healthy food. Furthermore, Bioactive compounds such as polysaccharides, proteins and nucleic acid are extracted from various species of Pleurotus tends the researcher to investigate more on this beneficial genus. This work is focused on reviewing the recent work published in the biodiversity and nutritional content of Pleurotus spp.
\end{abstract}

Keywords: Pleurotus spp., biodiversity, proximate analysis, nutritional values.

\section{INTRODUCTION}

Since centuries, mushrooms have been used as nourishment throughout the world due to its rich nutrients such as proteins, carbohydrates, lipids, minerals (phosphorous and potassium), and vitamins [1]. Mushroom nowadays considered as one of the most important functional food with many well-known therapeutic applications [2-6]. Based on historical point of view, the Chinese people introduced mushroom as a significant and well-being diet or in other words the "elixir of life". In addition, Mushroom has been prescribed as a remedial for hallucinogens purpose in spiritual ceremony within witchcrafts by Mexican Indians. The Greeks people were thought that mushrooms provided strength for the soldier or fighter in war. In the world, many species of mushroom have received a remarkable amount of interest, as they are substantial source of appetizing food with high dietary properties as well as medicinal values. Furthermore, both mushroom extract and metabolites are currently major concerns of related industries such as food additives manufactory, fermented beverages, antibiotics, pigments, pharmaceuticals [7], biofuel, industrial enzymes, vitamins, organic and fatty acids and sterols [8, 9]. For many years mushroom

*Address correspondence to this author at the Institute of Bioproduct Development (IBD), Universiti Teknologi Malaysia (UTM), 81310 UTM Johor Bahru, Johor, Malaysia; Tel: +6(07)5531573; Fax: +6(07)5569706;

E-mail: henshasy@ibd.utm.my cultivation is usually carried out using green house. However, nowadays beside solid state cultivation system using lignocellulosic biomass residues, cultivations were also successfully carried out in full submerged cultivation system under controlled sterile conditions to reduce the production time, increase in both volumetric and specific bioactive metabolites production, and to reduce the risk of contamination during mushroom cultivation $[10,11]$.

In this category, the genus Pleurotus (oyster mushroom) is an organoleptic fast growing fungus, which belongs to basidiomycota group. Although seventy species are discovered for this genus [12-14], only few of them are available in market such as $P$. florida, $P$. sajor-caju and $P$. ostreatus [15-17]. The biodiversity of Pleurotus is main concern of numerous researchers [18, 19]. Most of research studies were conducted with the aim of clarifying more about this genus and its identification in terms of morphological appearances. Recent molecular and biochemical techniques contribute a lot in this area. Needs for the pure and well-identified strains in order to breed, preserve the gene variability, and identify new species bring more emphasis on the importance of phylogenetic studies [20-22]. Most of pharmaceutical companies in south-east Asia especially China name medicinal mushrooms as a rich source of innovative bioactive molecules [1]. These products are extracted from fruiting body, mycelia and culture broth mainly as 
polysaccharides and proteins. Thus, in this review, the biodivertsity of the genus Pleurotus and the nutritional value of this important mushroom were discussed in details.

\section{BIODIVERSITY}

In the family of Pleurotaceae, species of the genus Pleurotus are second most important commercial mushroom [20, 23]. It is mainly due to their high nutritional, which can be applied as human diet and medicals. Pleurotus species can be grown in wild range of temperate and tropical areas as wild mushrooms of this genus distributes worldwide [12]. Table 1 presents widespread distribution of most studied Pleurotus species, their habitat and distinctive features. Although around 70 species of Pleurotus is recoded until now, but only few of them cultivated in industrial scale. Both techniques of solid state and submerged culture is already applied for cultivation of this mushroom in industry [12]. $P$. sajor-caju, $P$. citrinopileatus and $P$. florida are other extensive available Pleurotus mushrooms. Mushrooms commonly utilized by human

Table 1: Habitat, Geographical Distribution and Distinctive Features of most known Pleurotus spp. [26, 35]

\begin{tabular}{|c|c|c|c|c|}
\hline Species & Habitat & $\begin{array}{l}\text { Geographical } \\
\text { Distribution }\end{array}$ & $\begin{array}{l}\text { Similar } \\
\text { morphological } \\
\text { species }\end{array}$ & $\begin{array}{l}\text { Distinctive } \\
\text { Features }\end{array}$ \\
\hline P. calyptratus & Populus spp. & $\begin{array}{l}\text { central and eastern } \\
\text { Europe, Asia }\end{array}$ & P. dyinus & $\begin{array}{c}\text { The absence of stipe and } \\
\text { chlamydospores and the formation } \\
\text { of a pellicular veil }\end{array}$ \\
\hline P. cornucopiae & $\begin{array}{l}\text { Quercus, Alnus, Fagus, } \\
\text { Fraxinus, Acer, Prunus, } \\
\text { more usually Ulmus trees }\end{array}$ & Europe, Asia & P. citrinopileatus & $\begin{array}{l}\text { the convex to infundibuliform whitish } \\
\text { to yellow pilei, the fistulose- } \\
\text { dichotomic subcentral stipe, the } \\
\text { dimitic hyphal system and the } \\
\text { distinctive purple spore-print colour }\end{array}$ \\
\hline P. cystidiosus & $\begin{array}{l}\text { Ficw carica-broad- } \\
\text { leaved trees. }\end{array}$ & $\begin{array}{l}\text { Europe, Asia, north } \\
\text { America, south Africa }\end{array}$ & $\begin{array}{l}\text { P. abalones } \\
\text { P. smithii } \\
\text { P. purpureo- } \\
\text { olivaceus }\end{array}$ & $\begin{array}{l}\text { asexual synnematoid anamorphs } \\
\text { (assigned to Anfromycopsis); } \\
\text { oblongelliptical basidiospores, the } \\
\text { abundance of clavate pileocystidia } \\
\text { and cheilocystidia, }\end{array}$ \\
\hline P. dryinus & $\begin{array}{l}\text { Picea, Iuglans, Malus, } \\
\text { Alnus, Fagus and Ulmus }\end{array}$ & $\begin{array}{l}\text { Europe, Asia, north } \\
\text { America- North Africa }\end{array}$ & & $\begin{array}{l}\text { light beige to light brown pilei, } \\
\text { chlamydospores in culture, has a } \\
\text { distinct veil and dimitic hyphal } \\
\text { system }\end{array}$ \\
\hline P. eyngii & Umbelliferae, Compositae & Europe, Asia, Africa & & $\begin{array}{l}\text { White to brown pileus colors } \\
\text { scattered with numerous beige } \\
\text { squamules, the well-developed } \\
\text { central to subcentral stipe, the } \\
\text { relatively large basidiospores }\end{array}$ \\
\hline P. opuntiae & $\begin{array}{l}\text { Opuntia, Agave, Yucca } \\
\text { and Phy tolacca plants }\end{array}$ & $\begin{array}{c}\text { Mediterranean Europe, } \\
\text { South America, Africa, } \\
\text { Asia }\end{array}$ & & \\
\hline P. ostreatus & $\begin{array}{l}\text { Abies, Fagw, Populus, } \\
\text { Quercus, Betula, Picea, } \\
\text { Ulmus, Salix,alnw } \\
\text { Iuglans, }\end{array}$ & $\begin{array}{l}\text { Widespread around } \\
\text { the world }\end{array}$ & & $\begin{array}{c}\text { Cup shaped typical bivalve structure. } \\
\text { Known also as grey oyster } \\
\text { mushroom, tree oyster, and king } \\
\text { oyster mushroom. }\end{array}$ \\
\hline P. columbinus & $\begin{array}{c}\text { Abies, Picea, Fagus, Acer } \\
\text { and Ulmw }\end{array}$ & & $\begin{array}{l}\text { P. ostreatus var. } \\
\text { columbinus }\end{array}$ & $\begin{array}{c}\text { Dark grey-brown imbricate pilei, } \\
\text { dense anastomizing lamellae, } \\
\text { Monomitic hyphal system and can } \\
\text { grow at low temperatures on } \\
\text { different substrates. Known also as } \\
\text { blue oyster. }\end{array}$ \\
\hline P. djamor & & $\begin{array}{l}\text { Tropical region, } \\
\text { Indonesia, Malaysia, } \\
\text { Japan, Mexico }\end{array}$ & Agaricus djamor & $\begin{array}{l}\text { Known as Pink flamingo oyster } \\
\text { mushroom, Salmon mushroom, } \\
\text { Strawberry mushroom. }\end{array}$ \\
\hline P. pulmonarius & $\begin{array}{c}\text { Angiosperm wood } \\
\text { belonging to Fagus, } \\
\text { Populus, Sorbus, } \\
\text { Aesculus, Fraxinus, Betuh, } \\
\text { Quercus }\end{array}$ & $\begin{array}{l}\text { In warm and tropical } \\
\text { region, Asia }\end{array}$ & $\begin{array}{l}\text { P. ostreatus } \\
\text { P. populinus }\end{array}$ & $\begin{array}{c}\text { Small, paler caps compare to } P \text {. } \\
\text { ostreatus. Also known as lung } \\
\text { oyster, phoenix oyster, Indian oyster. }\end{array}$ \\
\hline
\end{tabular}


for their nutrition content as well as their immunomodulatory effects [15-17].

Species of the genus Pleurotus perform a wide variety of morphological characters in different climates and environment [12, 21, 24]. Earlier, morphological classification was applied for species identification of this genus. However it is not a preferred method in higher fungi as environment conditions, habitat and climate strongly influence the morphology of basidiomata. This morphological classification leads to confusing taxonomy of Pleurotus and misidentification of some species. As a result no unique conclusion will be given regarding taxonomy studies [20, 21, 25, 26]. White basidomata is a case in point. It is a distinctive feature of $P$. eryngii var. nebrodensis but recently it is also reports in some isolate of variety ferulae [24]. Besides incorrect naming of commercial strains make it more confusing [27]. The ambiguous taxonomy of Pleurotus species highlighted the importance of studies on genetic diversity, clarifying the misidentified species and strains in the literatures. [20]. Also, precise identified biological material is required for breeding programs and high quality production of mushroom [21, 22]. Besides, identification and preserving wild types of Pleurotus species from drastic diversity loss is critical as they are important biological sources for improving the characteristic of commercial cultivate mushrooms. Wild Pleurotus mushrooms are in danger of loss of genetic variability as a consequence of man's selection [28].

Phylogenetically based species is an appropriate alternative for developing species concepts in mushrooms [29]. In recent decades, various biochemical and molecular techniques applied for investigation of phylogenetic relationship and strain identification of Pleurotus population. Isozyme electrophoresis [21], sequence analysis of ribosomal DNA [30], internal transcribed spacer region (ITS) [22, 31], random amplified polymorphic DNA (RAPD)[3133], amplified fragment length polymorphism (AFLP)[28], restriction fragment length polymorphism (RFLP) [28] and mating compatibility test [27, 29, 33, 34] are among these techniques. Although extensive research conducted to clarify the obscure taxonomy of genus Pleurotus, still many questions is not fully addressed in the literature.

\subsection{Biological Species Concept}

One of the approaches to elucidate the delimitation of morphological species is to determine biological species and its complex structure [25, 27]. The biological species concept assist in clarifying systematic relationships among different taxa and speciation processes [26]. In contrast, there is a debate on the contribution of biological species to demonstrate evolutionary relationships with the strong basis of phylogenetic, which is almost in concordant with molecular phylogeny. Evaluating genetic divergence of Pleurotus taxa through integration of precise molecular techniques with biological species concept and geographical distribution lead to an explicit evolutionary mechanism identification [29].

Pleurotus population is subjected to many mating compatibility tests in which two intercompatible species are categorized as one biological species and intersterility groups [26, 27, 29, 34, 36, 37]. Mating behavior studies significantly contribute to phylogenetic studies, as the compatibility status between two known taxa represent the degree of gene flow between them [26]. Population of genus Pleurotus possesses tetrapolar (bifactorial) mating systems in their haplodikaryotic life cycle $[12,20,22,26,34]$. A haploid dikayotic mycelium only occurs once two compatible monokaryotic hyphae fuse together [20,34]. In fact the two diverse genetic loci named as $A$ and $B$ control the mating-type of homo basidiomycetes such as Pleurotus species and two monokaryons are compatible only when the alleles at both loci differ [26, 33, 34]. Mainly model species of Schizophyllum commune and Coprinopsis cinerae are studied to figure out the mating compatibility control of tetrapolar fungi regarding the genetic basis. However, positional cloning and degenerate PCR of $P$. djamor indicate similar genetic basis for it [34].

Vilgalys and Sun collected strains of Pleurotus with various geographic origins around the world and assessed the mating compatibility of the strains. As a result, eight different intersterility groups is reported [29]. In another study thirteen European Pleurotus species subjected to mating analysis through homokaryotes isolation of around 100 Pleurotus dikaryons by Zervakis and Bali [26]. Eight different intersterility groups were detected considering mating compatibility along with morphological, physiological and ecological characteristics of strains [26]. In other study, twelve biological species were defined among 25 Pleurotus morphological species mainly collected from Asia. Table $\mathbf{2}$ shows the biological species identified by these authors [27]. A simple comparison between the results of above-mentioned studies reveals few discrepancies in biological classification. 
Table 2: The Intersterility Groups in the Pleurotus Taxa Based on Mating Compatibility Tests

\begin{tabular}{|c|c|c|c|c|c|c|}
\hline References & \multicolumn{2}{|l|}{ [27] } & \multicolumn{2}{|l|}{ [26] } & \multicolumn{2}{|l|}{ [29] } \\
\hline Species & $\begin{array}{c}\text { Synonyms- } \\
\text { sub species taxa }\end{array}$ & $1 G^{*}$ & $\begin{array}{c}\text { Synonyms- } \\
\text { sub species taxa }\end{array}$ & IG & $\begin{array}{c}\text { Synonyms- } \\
\text { sub species taxa }\end{array}$ & IG \\
\hline P. ostreatus & $\begin{array}{l}\text { P. ostreatus var. } \\
\text { columbinus } \\
\text { P. djamor } \\
\text { P. flabellatus }\end{array}$ & I & $\begin{array}{c}\text { P. columbinus } \\
\text { P. florida } \\
\text { P. salignus } \\
\text { P. spodoleucus }\end{array}$ & I & & I \\
\hline P. pulmonarius & $\begin{array}{c}\text { P. eugrammus } \\
\text { P. eugrammus var. } \\
\text { brevisporus } \\
\text { P. sajor-caju } \\
\text { P. sapidus } \\
\text { P. sp. florida } \\
\text { P. opuntiae }\end{array}$ & II & $\begin{array}{l}\text { P. sajor-caju } \\
\text { P. sapidus }\end{array}$ & II & & II \\
\hline P. populinus & - & - & & III & & III \\
\hline P. calyptratus & & III & & VIII & & \\
\hline P. cornucopiae & $\begin{array}{l}\text { P. cornucopiae var. } \\
\text { citrinopileatus }\end{array}$ & IV & P. citrinopileatus & IV & P. citrinopileatus & IV \\
\hline P. corticatus & & V & - & - & - & - \\
\hline P. cystidiosus & P. abalonus & VI & P. abalonus & VII & $\begin{array}{c}\text { P. abalonus } \\
\text { P. smithii }\end{array}$ & VII \\
\hline P. djamor & - & - & $\begin{array}{c}\text { P. flabellatus } \\
P . \text { ostreatoroseus } \\
P . \text { salmoneostramineus } P \text {. } \\
\text { euosmus }\end{array}$ & V & $\begin{array}{c}\text { P. flabellatus } \\
\text { P. salmoneostramineus } \\
P . \text { salmonicolor }\end{array}$ & V \\
\hline P. dryinus & & VII & & IX & & VIII \\
\hline P. eryngii & & VIII & $\begin{array}{l}\text { P. ferulae } \\
\text { P. nebrodensis } \\
\text { P. hadamardii, } \\
\text { P. fossulatus }\end{array}$ & VI & P. fossulatus & VI \\
\hline P. nebrodensis & & IX & - & - & - & - \\
\hline P. purpureo-oliuacerrs & - & - & & $x$ & - & - \\
\hline P. salmoneostramineus & $\begin{array}{l}\text { P. rhodophyllus } \\
\text { P. ostreatoroseus }\end{array}$ & $X$ & - & - & - & - \\
\hline P. smithii & & $X I$ & - & - & - & - \\
\hline P. tuberregium & - & - & & $\mathrm{XI}$ & - & - \\
\hline P. ulmarius & & XII & - & - & - & - \\
\hline
\end{tabular}

${ }^{*}$ IG stands for intersterility groups.

$P$. smithii and $P$. nebrodensis considered as independent interincompatible species [27] while they were categorized as $P$. cystidiosus and $P$. eryngii subspecies respectively [29]. Moreover, $P$. salmoneostramineus was recorded as a subspecies of $P$. djamor in both reports in 1994 and 1994, separated as single intersterility groups [27]. Instead, $P$. djamor and one of its subspecies named $P$. flbellatus, identified as subspecies of $P$. ostreatus. The biological identification of $P$. florida is another disagreement between different categorizations. It has been reported as a member of $P$. pulmonarius species complex [27] whereas it has been found as subspecies of $P$. ostreatus complex too [26]. Existence of current speciation process could be give rise to this minute disagreement. A phylogenic study on P.eryngii species complex suggests current specification process of this taxon $[24,26]$. 


\subsection{Molecular and Biochemical Studies}

Despite precious information obtain form interfertility tests, but the need for more accurate comprehension of phylogenic relationship among species and specification mechanism of this genus increase the importance of precise means of species identification, especially for the strain which their geographical locations are in ambiguity [21]. Therefore, various molecular and biochemical techniques applied for this reason [27, 31]. One of the approaches is enzymes electrophoresis, which is subjected to 11 Pleurotus species [18], as eleven enzymatic activities were investigated regarding the number of genes and alleles involved in their production. Also a interspecies and intra species relationship is visualized through dendrogram was generated by neighbor-joining clustering method [21]. It demonstrates nine distinct clusters, which six clusters composed of one discrete species $(P$. dryinus, $P$. flabellatus, $P$. abalones, $P$. cystidiosus, $P$. eryngii, $P$. columbines and $P$. cornucopiae) while $P$. cystidiosus is splitting up to two clusters. The strains with different geographical location of Greece and U.S.A constitute these two clusters. These suggest the effect of geographical location on the gene flow and specification of Pleurotus species, which is supported by other authors too [26, 29]. In addition, the remained cluster composed two main subclusters. One includes $P$. ostreatus strains and the other one consist of $P$. pulmonarius, $P$. sajorcaju and $P$. sapidus. It should be note that all of later species were categorized as one biological species $[26,27,29]$. This may contribute to the justification of low genetic diversity among them. In general, the phylogeny study of these 11 species demonstrates an obvious delimitation of $P$. dryinus, $P$. flabellatus, $P$. eryngii and $P$. cornucopiae from other taxa. Moreover, The highest intraspecies diversity reported in $P$. cystidiosus and $P$. eryngii species respectively [21]. Different geographical origins of $P$. cystidiosus explain its high genetic diversity. Special host plant system of $P$. eryngii lead to high variation of isoenzyme pattern and set boundaries for spreading through conforming ecological niche [21].

\subsection{Pleurotus Species}

Systematic studies of mushroom through molecular studies along with biological species concept and geographical distribution proposed ancient history of some species. The importance of molecular phylogenetic studies is recognized when not noticeable data on the dispersal and origin of related taxa is attainable from fossil records of fungi [29]. They were also proposed an ancient evolving of $P$. cystidiosus, $P$. djamor, $P$. dryinus, and $P$. cornucopiae intersterility groups through sequence analysis of $5^{\prime}$ portion of the nuclear encoded large subunit (LSU) rDNA. These species complexes are distributed widespread around the word. Moreover, they believed tight branching of $P$. ostreatus, $P$. pulmonarius also, $P$. populinus, $P$. eryngii species complex in related phylogram reveal their recent lineage in the Northern Hemisphere. Furthermore, phylogenetically based pattern of genetic divergence of rDNA internal transcribed spacer (ITS) region supports allopatric speciation in Pleurotus taxa with in the Northern Hemisphere. The high isoenzyme pattern variation of $P$. cystidousus suggests allopatric speciation of some Pleurotus species. It indicates the significant of biogeography in accordance to molecular speciation studies. The ephemeral fruiting pattern is one of the boundaries of understanding the distribution of mushrooms species. Previously, other mushroom groups indicated that geographical isolations with genetic divergence still have compatibility attitude. The contribution of geographical isolation to Pleurotus speciation is supported by high level of bootstraps for distinct geographical populations. It should be noted that polymorphic analysis of ITS possess adequate variation for elucidating phylogenetic relationship among geographically isolates as it's substitution rate was seven times higher than in the LSU sequences [29].

The geographical pattern of specification stem from dispersal and vicariance events on the basis of molecular studies and historical biogeography distribution. P. cystidiosus, P. djamor, P. dryinus, and $P$. cornucopiae, which are broadly distribute across both Hemispheres are regarded as ancient origin, while $P$. ostreatus, $P$. pulmonarius, $P$. populinus, $P$. eryngii species viewed evolved more recently in this speciation pattern. Later, it is mentioned species seems to be distributed solely within the Northern Hemisphere. Two historical hypotheses were proposed to address this distribution. One of these theories dated back the origin of higher taxa to Cambrian or earlier bases on continental drift theory. This theory believed the existence of ancient species before the Pangean continent break up around 200 million years ago. Moreover, some recent species are result of Laurasia breakup in events occurring in the Northern Hemisphere. It is expected to observe similar gross vicariance pattern across the Northern and Southern in this scenario. Another hypothesis, regular and 
intermittent dispersal of species are responsible for the geographical speciation pattern. Therefore in this theory older species is distributed across wider geographical areas than more recently one [29].

\section{NUTRITIONAL VALUE}

Consumers ate mushrooms for their palatability, nutritional value and medicinal value. Palatability can be elaborate as color, texture, flavor and taste. Higher Basidiomycetes mushrooms possess certain natural benefits in terms of dietary supremacy when compared with vegetarian diet. These include high protein content, essential amino acids enabling it to be as substitute for meat diet), a chitin rich wall acts as a source of dietary fiber, vitamin content (B1, B2, B12, C, $D$, and $E$ ), micro and macro-elements, carbohydrates, low fat content, and almost zero cholesterol content $[38,39]$. The scientific works involves the analysis of the proximate analysis and also study the diversity of amino acids, fatty acids, vitamins, minerals, and nucleic acid present in this mushroom. Due to high amount value of proteins, mushrooms contribution can used to bridge the protein malnutrition gap and low of starch and cholesterol content, this mushroom suitable for diabetic and heart disease patients. Therefore, the bioaccumulation potential of nutrients by fungi enriched with essential elements for human health has been investigated [40].

It is well known that the composition or ingredients of Pleurotus species is affected by the diversity of its genetic framework or makeup, which leads to variety strain differences and environmental conditions. The edible mushroom Pleurotus species are nutritious foods, low in calories and in fat, luxuriant in protein, chitin, vitamins and minerals [41, 42].

\subsection{Proximate Compositions of Pleurotus}

Proximate study of certain compound would encompass the analysis content of moisture, crude protein, crude fat, crude fiber, ash and energy. Generally, fresh Pleurotus mushroom contain $85-95 \%$ moisture [43]. Proximate composition of Pleurotus species is highly varied according to its species and substrate. Table 3 shows the proximate composition within different species while Table 4 showed the nutritional compositions of $P$. ostreatus when using different substrates. Soybean straw showed maximum protein, fat, and ash with the values $24.66 \%, 2.82 \%$ and $6.70 \%$ respectively. The fat content on dry weight basis ranged between $2.56 \%$ to $2.82 \%$ and for the moisture ranged between $88.51 \%-89.88 \%$ of $P$. ostreatus. Rice straw was given maximum percentage of about $7.70 \%$ for crude fiber followed by soybean and the minimum was found when using soybean straw $(7.15 \%)$ alone during cultivation. A research done by Chye et al. (2008) suggested that the general ash content of edible wild Pleurotus sp. was found to be around $5.64 \%$ [44]. Another kind of strain which is $P$. eryngii are known rich in carbohydrate, fiber, and protein and low in ash and fat, which was in agreement with the previous study [45]. The fruiting body of $P$. ostreatus contains approximately 100 of different bioactive compounds, which mainly considered as a potential new source of dietary fiber [5].

\subsection{Protein Content}

It was reported that the protein contents of mushrooms are affected by a number of factors namely: the type of mushroom, the stage of maturation, the part mushroom body, availability of nitrogen content in the medium and the harvest location [65]. Table 3 shows the protein content of different Pleurotus species. Pleurotus was known as a good source of protein especially for vegetarian because this edible mushroom contains some essential amino acid for human intakes [53]. The digestibility of edible mushroom Pleurotus species proteins is as same as that of plants $(90 \%)$ and comparable with meat $(99 \%)$ [53]. According to Patil (2012), the protein content stated as a percentage of a dry weight in mushrooms in general in range between 10 and $40 \%$, and varied extensively among and within the species. However, the average of protein content of Pleurotus is most common between 20 and 25\% [64].

\subsection{Amino Acid Content}

Edible mushroom, Pleurotus contains $40 \%$ of the essential amino acids required for human intake and thus it considered as potential diet for people suffering from malnutrition problem [66]. Moreover, mushroom proteins contain all the essential amino acids needed in the human diet and rich with lysine and leucine which are absent in most staple cereal foods [67].

A total of 18 amino acids were recorded in Pleurotus species (Table 5). Generally, the amino acid constituents were comparable in all species as they belong to the same family of Pleurotus. Tryptophan was discovered to be the minimum abundant essential amino acids in the Pleurotus species [42]. Table 6 shows the amino acid profile of $P$. ostreatus when 
Table 3: Proximate Composition of Pleurotus Species

\begin{tabular}{|c|c|c|c|c|c|c|c|}
\hline $\begin{array}{l}\text { Pleurotus } \\
\text { Species }\end{array}$ & $\begin{array}{c}\text { Moisture } \\
\text { (fresh weight) } \\
{[\%]}\end{array}$ & $\begin{array}{c}\text { Crude } \\
\text { Protein } \\
\text { [\%] }\end{array}$ & $\begin{array}{c}\text { Crude fat } \\
\text { [\%] }\end{array}$ & $\begin{array}{c}\text { Carbohydrate } \\
\text { (Total) } \\
{[\%]}\end{array}$ & $\begin{array}{c}\text { Crude fiber } \\
\text { [\%] }\end{array}$ & $\begin{array}{l}\text { Ash } \\
{[\%]}\end{array}$ & References \\
\hline P. florida & 91.5 & 27.0 & 1.6 & 58.0 & 11.5 & 9.3 & {$[46]$} \\
\hline P. ostreatus & 90.8 & 30.4 & 2.2 & 48.9 & 8.7 & 9.8 & {$[47]$} \\
\hline P. ostreatus & $73.7-90.8$ & $10.5-30.4$ & $1.6-2.2$ & $57.6-81.8$ & $7.5-8.7$ & $6.1-9.8$ & [49] \\
\hline P. ostreatus & 4.46 & 20.82 & 0.56 & 68.35 & 45.50 & 5.81 & {$[50]$} \\
\hline P. sajor-caju & 90.1 & 26.6 & 2.0 & 50.7 & 13.3 & 6.5 & [51] \\
\hline P. sajor-caju & - & 21.22 & 0.25 & 51.19 & 16.68 & 3.09 & [48] \\
\hline P. ferulae & 91.11 & 30.3 & 5.71 & 47.8 & 11.2 & 4.96 & [52] \\
\hline $\begin{array}{c}P . \\
\text { nebrodensis }\end{array}$ & 87.74 & 27.7 & 7.35 & 46.2 & 15.7 & 3.84 & {$[52]$} \\
\hline P. sapidus & 90.53 & 20.4 & 4.85 & 57.1 & 12.3 & 5.32 & [52] \\
\hline P. flabellatus & 90.95 & 2.75 & 0.103 & - & 1.084 & 0.974 & [53] \\
\hline
\end{tabular}

Note:a: Water and dry matter contents are presented based on fresh weight, others are presented based on dry weight.

Table 3: Proximate Composition of Pleurotus Species (Cont.)

\begin{tabular}{|c|c|c|c|c|c|c|c|c|}
\hline $\begin{array}{l}\text { Pleurotus } \\
\text { Species }\end{array}$ & $\begin{array}{c}\text { Moisture } \\
\text { [\%] }\end{array}$ & $\begin{array}{c}\text { Protein } \\
\text { [\%] }\end{array}$ & $\begin{array}{c}\text { Fiber } \\
{[\%]}\end{array}$ & $\begin{array}{l}\text { Ash } \\
{[\%]}\end{array}$ & $\begin{array}{l}\text { Fat } \\
{[\%]}\end{array}$ & $\begin{array}{c}\text { Carbohydrate } \\
{[\%]}\end{array}$ & $\begin{array}{l}\text { Energy } \\
\text { kcal/100g }\end{array}$ & Reference \\
\hline P. ostreatus & - & 24.90 & - & 7.62 & 2.08 & 61.9 & - & [54] \\
\hline P. ostreatus & $85-87$ & $17-42$ & $24-31$ & - & $0.5-5$ & $37-48$ & - & [43] \\
\hline P. ostreatus & 84.3 & 14.7 & - & 5.69 & 1.53 & 78.1 & 385 & [55] \\
\hline P. ostreatus & - & 23.52 & 22.44 & 7 & 4.1 & 43.134 & - & [58] \\
\hline P. ostreatus & - & 27.13 & 20.36 & 20.55 & 4.89 & 32.50 & - & [59] \\
\hline P. ostreatus & 8.2 & 33.5 & & 7.1 & 2.3 & 48.9 & 350 & [60] \\
\hline P. ostreatus & - & 7.02 & 10.83 & 5.72 & 1.4 & 85.86 & 416 & {$[61]$} \\
\hline P. ostreatus & 90.0 & 28.4 & 27.4 & 11.4 & 3.8 & 29.6 & & [63] \\
\hline
\end{tabular}

cultivated on diverse agricultural substrates. According to Table 7, amino acid in edible Pleurotus species were divided into several groups regarding taste characteristic [68, 69]. Palatable taste (aspartic and glutamic) is belong to group 1 , group two involve sweet taste amino acids (alanine, glycine, serine, threonine), for bitter taste amino acid was classification as group 3 including arginine, histidine, isoleucine, leucine, methionine, phenylalanine, tryptophan and valine.

Among essential amino acids, lysine, leucine, phenylalanine and threonine were present in high 
Table 4: Effects of Different Substrates on Proximate Compositions of Pleurotus ostreatus [64]

\begin{tabular}{|c|c|c|c|c|c|}
\hline Substrate & $\begin{array}{c}\text { Moisture } \\
{[\%]}\end{array}$ & $\begin{array}{c}\text { Protein } \\
{[\%]}\end{array}$ & $\begin{array}{c}\text { Fat } \\
{[\%]}\end{array}$ & $\begin{array}{c}\text { Crude Fiber } \\
{[\%]}\end{array}$ & $\begin{array}{c}\text { Total carbohydrate } \\
{[\%]}\end{array}$ \\
\hline \hline [\%]
\end{tabular}

amounts; valine, isoleucine, histidine and arginine in moderate concentrations and methionine and tryptophan in low amounts. On the other hand, nonessential amino acids such as glutamic acid, aspartic acid, serine, glycine and alanine were found in high amount whereas proline, histidine, and tyrosine content were low [57].

The most abundant amino acids in $P$. eryngii were Asp and Glu and furthermore, the low content amino acids were Cys, Met and His. Even though mushrooms content are rich source of with proteins, several of these proteins have not been identified and even fewer characterized. Some researchers mentioned the protein contents in $P$. ostreatus are varied according to strains, physical and chemical differences in growing medium composition of the substrate, size of the pileus, and harvest time [5]. However, Proteins of Pleurotus sp. mushroom still have superior quality because some of the members of this genus contain complete proteins with the well distribution of essential amino acids, as well as non-essential amino acids [5].

\subsection{Carbohydrate and Fiber}

Carbohydrates contribute around $50-60 \%$ of mushroom dry weight basis, which consists of various compounds: sugars (monosaccharides, disaccharide and oligosaccharides) and directly associated in synthesis process of polysaccharides (glycans) [5, 70]. Carbohydrates are mainly deposit in $P$. ostreatus as polysaccharides are represented by glycogen, indigestible fiber (cellulose, dietary fibers, chitin, $\alpha$ - and $\beta$ - glucans) and other hemicelluloses (mannans, xylans and galactans) [71].

Table 3 shows the proximate analysis of fresh Pleurotus. $P$. ostretaus has very high carbohydrate content with $57 \%$ and $14 \%$ fiber. However, the fibers of plants and mushroom are different. Major sources of fiber are cellulose and other un-digestible cell wall polymers. Although fiber is un-digestible, it has substantial nutritional role in human physiological processes. The crude fiber content of $P$. sajor caju in biomass was found to be $5.5 \pm 0.48 \%$ [57]. Carbohydrates generally constitute cell wall of mushroom. Glucan and mannan are the two main polysaccharides of the cell wall. Glucan as food has beneficial effect for lowering the serum cholesterol, a risk for cardio-vascular disease [72], while mannan has radio-protective effect [73]. $P$. ostreatus characterized by the production of special type of intracellular and extracellular immunomodulatory $\beta$-glucan polysaccharides named pleuran $[74,75]$. However, it is also quite interesting that mushrooms contain glycogen and even chitin, which is a group of polysaccharides occurring in animals instead of starch and cellulose, typically in plants. Glycogen is a kind of reserved polysaccharide by mushrooms. Limited literature data report the contents of $50-100 \mathrm{~g} \mathrm{~kg}^{-1}$ dry mass. The nutritional importance for humans is limited due to its content in meat and producible particularly in human liver [70]. Chitin is a water insoluble, structural $\mathrm{N}$ containing polysaccharide which is characterized by $\beta$ $(1,4)$-branched $\mathrm{N}$-acetylglucosamine units. Through partially deacetylation process of chitin, yields chitosan.

\subsection{Mineral Content}

In general all edible mushrooms also are a good source of minerals (Table 8). Like all living organisms, Pleurotus mushrooms have a mix of minerals and their fruiting bodies are characterized by high level of mineral constituents. It contain minerals such as $\mathrm{K}, \mathrm{P}$, $\mathrm{Na}, \mathrm{Ca}, \mathrm{Mg}$ are the majority mineral elements in mushrooms and others constituents including $\mathrm{Cu}, \mathrm{Zn}$, $\mathrm{Fe}, \mathrm{Mo}, \mathrm{Cd}$ are the minor components [46]. One of the highest mineral in all higher species of Pleurotus is $\mathrm{Cu}$ content varied from 12.2 to $21.9 \mathrm{ppm}$. Content of $\mathrm{Ca}$ and $\mathrm{Pb}$ varied from $0.3-0.5 \mathrm{ppm}$ and from 1.5- 3.2 ppm, respectively in all Pleurotus species [46]. Table 9 shows that the mineral content of $P$. ostreatus is varied according to the substrate composition. From this table, it can be concluded that $\mathrm{Ca}(330 \mathrm{mg} / 100 \mathrm{~g})$ will be the 
Table 5: Essential Amino Acids of Different Edible Pleurotus Species Compared to Egg

\begin{tabular}{|c|c|c|c|c|c|c|c|c|c|c|}
\hline Amino acids & $\begin{array}{c}P . \\
\text { ostreatu } \\
s\end{array}$ & $\begin{array}{c}P \\
\text { florida }\end{array}$ & $\begin{array}{c}P . \\
\text { cystidios } \\
\text { us }\end{array}$ & $\begin{array}{c}P . \\
\text { abalanos } \\
\text { (mg/g } \\
\text { fruit } \\
\text { body) }\end{array}$ & $\begin{array}{c}P \\
\text { sajor- } \\
\text { caju }\end{array}$ & $\begin{array}{c}P . \\
\text { djamor } \\
\begin{array}{c}\text { (mg/g dry } \\
\text { weight) }\end{array}\end{array}$ & $\begin{array}{c}P . \\
\text { ferulae } \\
\text { (mg/g dry } \\
\text { weight) }\end{array}$ & $\begin{array}{c}P . \\
\text { nebroden } \\
\text { sis } \\
\text { (mg/g dry } \\
\text { weight) }\end{array}$ & $\begin{array}{c}P . \\
\text { Sapidus } \\
\text { (mg/g dry } \\
\text { weight) }\end{array}$ & Egg \\
\hline Leucine & $\mathrm{Nd}$ & 7.5 & $\mathrm{Nd}$ & 0.43 & 7.0 & 4.14 & 12.9 & 5.66 & 7.85 & 8.84 \\
\hline Isoleucine & 0.19 & 5.2 & 0.23 & 0.27 & 4.4 & 4.3 & 12.6 & 10.1 & 8.23 & 6.64 \\
\hline Valine & 0.02 & 6.9 & 0.09 & 0.44 & 5.3 & 5.57 & 21.1 & 11.8 & 12.4 & 7.25 \\
\hline Tryptophan & 0.02 & 1.1 & 0.14 & 1.11 & 1.2 & 3.16 & 2.51 & 0.53 & 0.73 & 1.60 \\
\hline Lysine & 0.19 & 9.9 & 0.32 & 0.75 & 5.7 & 3.65 & 32.5 & 22.2 & 21.2 & 6.64 \\
\hline Thereonine & $\mathrm{Nd}$ & 6.1 & 0.42 & 0.60 & 5.0 & 3.73 & 9.53 & 5.62 & 5.59 & 5.07 \\
\hline Phenyalanine & 0.19 & 3.5 & 0.28 & 0.45 & 5.0 & 2.69 & 4.47 & 3.19 & 3.29 & 5.84 \\
\hline Methionine & 0.16 & 3.0 & $\mathrm{Nd}$ & 1.81 & 1.8 & 1.23 & 11.38 & 5.76 & 5.56 & 3.15 \\
\hline Histidine & 0.12 & 2.8 & $\mathrm{Nd}$ & 0.82 & 2.2 & 1.84 & 22.3 & 8.96 & 9.58 & 2.38 \\
\hline Cysteine & 0.13 & & 0.05 & 4.48 & 37.6 & 5.86 & 12.96 & 6.75 & 7.81 & 47.22 \\
\hline Aspartic acid & $\mathrm{Nd}$ & & 0.51 & 0.56 & & 8.64 & 3.62 & 2.61 & 6.24 & \\
\hline Serine & 0.71 & & 1.16 & 0.54 & & 6.01 & 8.68 & 4.54 & 5.57 & \\
\hline Glutamic acid & 0.12 & & 0.14 & 2.49 & & 7.11 & 5.66 & 7.06 & 2.46 & \\
\hline Proline & 2.13 & & 3.94 & 12.50 & & 4.66 & 8.61 & 4.56 & 6.63 & \\
\hline Glycine & 0.08 & & $\mathrm{Nd}$ & 0.66 & & 5.53 & 8.06 & 4.65 & 6.23 & \\
\hline Alanine & 0.02 & & 0.05 & 27.91 & & 5.50 & 3.29 & 2.47 & 3.62 & \\
\hline Arginine & 4.08 & & 7.33 & & & 7.36 & 11.8 & 6.82 & 6.49 & \\
\hline Tyrosine & & & & & & 3.35 & 192 & 113 & 119 & \\
\hline Total A. acid & & & & & & 84.4 & & & & \\
\hline References & [77] & [78] & [77] & [79] & [78] & {$[52]$} & [52] & {$[52]$} & [52] & {$[47]$} \\
\hline
\end{tabular}

Table 6: Amino Acid Profile of $P$. ostreatus Cultivated on Different Agricultural Wastes [64]

\begin{tabular}{|c|c|c|c|c|c|c|}
\hline Amino acids & $\begin{array}{l}\text { Soybean } \\
\text { straw }\end{array}$ & Paddy straw & Wheat straw & $\begin{array}{l}\text { Soybean and } \\
\text { paddy straw }\end{array}$ & $\begin{array}{l}\text { Soybean and } \\
\text { wheat straw }\end{array}$ & $\begin{array}{l}\text { Wheat and } \\
\text { paddy straw }\end{array}$ \\
\hline Alanine & 25.1 & 20.2 & 28.3 & 20 & 23.7 & 18.5 \\
\hline Arginine & 29.4 & 22.2 & 23.5 & 32.0 & 28.2 & 20.6 \\
\hline Aspartic acid & 45.1 & 38.7 & 32,3 & 39.2 & 36.4 & 29.8 \\
\hline Cystine & 5.6 & 3.7 & 6.0 & 3.9 & 3.2 & 3.5 \\
\hline Glutamic acid & 64.2 & 58.5 & 56.8 & 63.1 & 59.0 & 55.7 \\
\hline Glycine & 9.2 & 9.5 & 11.8 & 7.0 & 6.9 & 7.2 \\
\hline Histidine & 15.9 & 16.4 & 19.2 & 12.2 & 15.8 & 13.0 \\
\hline Lysine & 33.6 & 36.2 & 18.9 & 24.7 & 20.2 & 28.8 \\
\hline Methione & 4.3 & 5.1 & 3.6 & 4.9 & 3.9 & 3.2 \\
\hline Phenyl alanine & 20.2 & 16.5 & 18.2 & 16.5 & 17.2 & 19.0 \\
\hline Proline & 16.8 & 13.8 & 13.8 & 15.8 & 10.9 & 14.2 \\
\hline Serine & 18.5 & 16.3 & 17.2 & 14.3 & 15.8 & 12.6 \\
\hline Thereonine & 32.5 & 29.0 & 26.3 & 28.0 & 28.5 & 24.8 \\
\hline Tryptophan & 5.2 & 6.9 & 6.5 & 4.7 & 5.3 & 5.6 \\
\hline Tyrosine & 12.3 & 9.7 & 9.2 & 11.0 & 10.5 & 8.6 \\
\hline Valine & 30.1 & 28.4 & 25.0 & 27.5 & 28.7 & 24.2 \\
\hline Leucine & 37.0 & 35.2 & 28.6 & 32.9 & 26.5 & 23.8 \\
\hline Isoleucine & 21.5 & 19.2 & 18.5 & 18.0 & 14.6 & 16.0 \\
\hline Glutamine & 5.6 & 5.2 & 6.2 & 5.3 & 4.6 & 4.8 \\
\hline
\end{tabular}

highest mineral content when $P$. ostreatus was cultivated on soybean and rice straw.

Some minerals are essential to a healthy diet such as calcium, phosphorous, potassium and sodium whereas others can be toxic such as lead, mercury, cadmium and aluminum. The mineral proportions are varied; depend on the species, age and also on the shape of the fruiting body. Mushrooms have a mix of minerals, and their fruiting bodies are characterized by 
Table 7: Amino Acid Contribution for Taste Characteristic of Several Pleurotus Species

\begin{tabular}{|c|c|c|c|c|c|c|c|}
\hline $\begin{array}{c}\text { Taste } \\
\text { characteristics }\end{array}$ & $\boldsymbol{P}$. djamor & $\boldsymbol{P}$. ferulae & $\boldsymbol{P}$. nebrodensis & $\boldsymbol{P}$. sapidus & $\begin{array}{c}\boldsymbol{P} \text {. } \\
\text { cystidiosus }\end{array}$ & $\boldsymbol{P}$. ostreatus & $\boldsymbol{P}$. abalonus \\
\hline \hline Palatable & 15.8 & 53.6 & 34.0 & 33.7 & 1.21 & 0.84 & 6.29 \\
Sweet & 20.8 & 39.1 & 20.5 & 26.3 & 5.01 & 2.25 \\
Bitter & 30.3 & 74.8 & 42.0 & 44.9 & 0.74 & 0.78 \\
Tasteless & 7.00 & 16.3 & 9.22 & 11.4 & 0.37 & 0.21 & 1.76 \\
\hline Reference & \multicolumn{2}{|c|}{$[52]$} & & {$[77]$} & {$[79]$} \\
\hline
\end{tabular}

Table 8: Mineral Contents Of Different Pleurotus Strains (mg/g dry Weight)

\begin{tabular}{|c|c|c|c|c|c|c|c|c|}
\hline Mineral element & P. djamor & P. ferulae & P. nebrodensis & $\begin{array}{c}P . \\
\text { sapidus }\end{array}$ & $\begin{array}{c}P . \\
\text { ostreatus }\end{array}$ & $\begin{array}{c}P . \\
\text { ostreatus }\end{array}$ & P. sajor-caju & P. florida \\
\hline $\begin{array}{c}\mathrm{Ca} \\
\mathrm{Mg} \\
\mathrm{P} \\
\mathrm{K} \\
\mathrm{Fe} \\
\mathrm{Zn} \\
\mathrm{Mn} \\
\mathrm{Se} \\
\mathrm{As} \\
\mathrm{Na}\end{array}$ & $\begin{array}{l}1.42 \\
1.21 \\
7.57 \\
12.3 \\
0.59 \\
0.18\end{array}$ & $\begin{array}{l}0.23 \\
0.85 \\
4.99 \\
16.2 \\
0.07 \\
0.08\end{array}$ & $\begin{array}{l}0.17 \\
0.79 \\
5.10 \\
16.3 \\
0.05 \\
0.02\end{array}$ & $\begin{array}{l}0.84 \\
1.19 \\
5.13 \\
14.3 \\
0.19 \\
0.07\end{array}$ & $\begin{array}{c}35.9 \\
16.395 \\
- \\
- \\
55.45 \\
26.565 \\
2.85 \\
0.011 \\
0.1\end{array}$ & $\begin{array}{c}33.0 \\
\text { N.D } \\
1348 \\
3793 \\
15.2 \\
837\end{array}$ & $\begin{array}{c}22.15 \\
20.22 \\
- \\
- \\
33.45 \\
20.9 \\
2.87 \\
0.025 \\
0.095\end{array}$ & $\begin{array}{c}33.7 \\
13.4 \\
- \\
- \\
43.2 \\
16 \\
2.7 \\
0.013 \\
0.083\end{array}$ \\
\hline References & [52] & [52] & [52] & [52] & {$[47,80]$} & {$[47]$} & {$[47,80]$} & {$[47,80]$} \\
\hline
\end{tabular}

Table 9: Effect of Different Substrates on Mineral Content (mg/100g) of Pleurotus ostreatus [64]

\begin{tabular}{|c|c|c|c|c|c|c|}
\hline Substrate & $\mathrm{Ca}$ & $\mathbf{P}$ & $\mathrm{Fe}$ & $\mathrm{Na}$ & $\mathbf{K}$ & $\mathrm{K} / \mathrm{Na}$ ratio \\
\hline Soybean straw & 300 & 1000 & 14.35 & 310 & 2320 & 7.48 \\
\hline Rice straw & 296 & 920 & 14.94 & 290 & 2260 & 7.79 \\
\hline Wheat straw & 270 & 810 & 13.88 & 305 & 2100 & 6.88 \\
\hline Soybean and paddy straw & 330 & 870 & 15.62 & 295 & 2100 & 7.11 \\
\hline Soybean and wheat straw & 260 & 910 & 14.20 & 260 & 2000 & 7.69 \\
\hline Wheat and paddy straw & 240 & 790 & 13.13 & 275 & 1900 & 6.90 \\
\hline S.E. & 4.18 & 8.14 & 0.16 & 4.16 & 8.72 & - \\
\hline C.D. at $5 \%$ & 12.45 & 24.25 & 0.47 & 12.39 & 25.90 & - \\
\hline
\end{tabular}

high levels of mineral constituents. In general, mushrooms contain significant amounts of phosphorus, sodium, and potassium among the macro-minerals in its content, while on the other hand, iron and zinc are the most ample elements among the trace minerals been analyzed in it. Among the micro-minerals measured, the iron and zinc are the most abundant elements among the trace minerals analyzed. Other than that, Pleurotus species would provide a useful source of phosphorus, potassium, iron, zinc, calcium, magnesium, manganese, and copper [43]. Therefore, the addition of Pleurotus species in diet could be one of the approaches for fighting iron, zinc, and other micronutrient deficiencies. Overall, the contents of ash and particularly of phosphorus and potassium are somewhat higher than if not at least comparable to that content in vegetable [70]. As shown, the Pleurotus species can provide a useful source of phosphorus, potassium, iron, zinc, calcium, magnesium, manganese, and copper [76]. Thus, the addition of highly nutritional mushrooms in human diet could be one of the solutions for combating iron, zinc, and other micronutrient deficiencies. 


\subsection{Vitamins}

Wild Mushrooms are relatively good source of vitamins than cultivated mushrooms especially the fruit bodies which is rich in vitamins mainly Thiamine (B1), Riboflavin (B2), C and ergocalcoferol [58]. It has been published that all edible mushrooms are a beneficial source for several vitamins such as thiamine (Vitamin $B_{1}$ ), riboflavin (vitamin $B_{2}$ ) $[76,81,82]$, niacin, biotin and vitamin $C$ (ascorbic acid). This was further supported by Isikhuemhen et al. (2009) who claimed that mushrooms appear to be a good source of vitamins, including thiamine, riboflavin, niacin, biotin and ascorbic acid aside than minerals. Mattila et al. (2001) reported that the vitamin of group B particularly are thamine, riboflavin, pyridoxine, pantotene acid, nicotinic acid, nicotinamid, folic acid and cobalamin whilst other vitamins such as ergosterol, biotin, phytochinon and tocopherols presence are also detected [82].

According to Teichmann et al., 2007, was shown that vitamin $D_{2}$ reaching the highest amount in wild mushroom than dark cultivated $A$. bisporus [83]. Edible mushrooms also comprising in small amount of vitamin $C$ and lack of Vitamins $A$, Vitamins $D$ and last but not least of Vitamin $D$ [53]. Table 10 shows the vitamin properties in the several Pleurotus species from literature review after analyzed. From this table, was shown that the oyster mushroom are rich in viamins such as vitamin C, Vitamin B complex including Thiamin, Riboflavin, Niacin, Folic Acid and Vitamin B12. Niacin is very important in human diet and with the high doses at $1 \mathrm{~g}$ to $5 \mathrm{~g}$ everyday is very useful to help control blood cholesterol [84]. Table 11 also presented Vitamin content of $P$. ostreatus when cultivated on different lignocellulosic wastes. From this table, it is concluded that the thiamine ranges between 0.004 to $0.008 \mathrm{mg} / 100 \mathrm{~g}$ and for the riboflavin is between 0.037 to $0.298 \mathrm{mg} / 100 \mathrm{~g}$. Mushroom in conserve, showed the lowest vitamins from the others mushroom.

\subsection{Fatty Acids Composition}

In mushrooms, the fat content is very low as compared to carbohydrates and proteins. The fats present in mushroom fruiting bodies are dominated by unsaturated fatty acids [51]. Fatty acid is very important as a source of energy yielding substances, especially for unsaturated fatty acids was used to the hypocholesterolemic or hypolipidemic activity for biomedical part. Pleurotus mushroom are low in fat content, but contain some essential fatty acids (Table 12). However, mushrooms are not considered as a significant source of essential fatty acids for fulfilling the requirements of human body. Oleic acid is the major monounsaturated fatty acid while linoleic acid is the major polyunsaturated fatty acid in $P$. ostreatus [5]. Tables 12 and 13 show the fatty acid compositions of some Pleurotus species. It was also reported that the most common monounsaturated fatty acid present in fungi is oleic acid (C18:I) [57]. The highest levels of SFA $(20.2 \%)$ with the main contribution from palmitic acid (C16:0; 11.2\%), followed by pentadecanoic acid (C15:0; 2.55\%) and stearic acid (C18:0; 2.53\%). Among PUFA (69.1\%), linoleic acid (C18:2n-6c; $68.1 \%$ ) was the most common and abundant in percentage [55].

Table 10: Vitamin $B_{1}$ and $B_{2}$ Content in Edible Pleurotus ssp [85]

\begin{tabular}{|c|c|c|c|}
\hline Species & Common name & B1(mg/100g) & B2 (mg/100g) \\
\hline \hline & Mushroom in conserve & 0.004 & 0.037 \\
Pleurotus spp. & Oyster salmon mushroom & 0.037 & 0.107 \\
& Oyster white mushroom & 0.025 & 0.075 \\
\hline
\end{tabular}

Table 11: Vitamin Content of $P$. ostreatus when Cultivated on Different Lignocellulosic Wastes [86]

\begin{tabular}{|c|c|c|c|c|}
\hline Substrate & Thiamin & Riboflavin & Pyridoxin & Niacin \\
\hline \hline Millet stalk & 0.14 & 0.12 & 0.25 & 0.07 \\
Wheat stalk & 0.15 & 0.19 & 0.21 & 0.20 \\
Cotton stalk & 0.23 & 0.23 & 0.21 & 1.43 \\
Soybean stalk & 0.93 & 0.67 & 0.21 & 0.59 \\
\hline
\end{tabular}


Table 12: Fatty Acids Composition of Pleurotus Species

\begin{tabular}{|c|c|c|c|c|c|c|c|c|}
\hline \multirow[t]{2}{*}{ Fatty acids } & \multirow[b]{2}{*}{$\begin{array}{l}\text { No. of } \\
\text { carbon }\end{array}$} & \multicolumn{7}{|c|}{ Percentage (\%) } \\
\hline & & P. sajor-caju & $\begin{array}{c}\text { P. sajor- } \\
\text { caju }\end{array}$ & P. cystidiosus & P. pulmonarius & P. floridanus & P. sapidus & $\begin{array}{c}\text { P. sajor- } \\
\text { caju }\end{array}$ \\
\hline Caprylic acid & C8:0 & - & 0.92 & - & - & - & - & - \\
\hline Pelargonic acid & C9:0 & - & - & 0.26 & 0.2 & 0.32 & 0.25 & 0.32 \\
\hline Capric acid & C10:0 & - & - & 0.33 & 0.18 & 0.13 & 0.2 & 0.18 \\
\hline Lauric acid & C12:0 & 0.69 & - & - & 0.45 & & 0.12 & 0.1 \\
\hline Myristic acid & C14:0 & 3.14 & 0.18 & - & - & - & - & - \\
\hline Pentadecanoic acid & C15:0 & 1.35 & & 4.06 & 1.56 & 2.12 & 4.43 & 5.58 \\
\hline Palmitic acid & C16:0 & 24.16 & 5.34 & 27.04 & 21.69 & 27.82 & 37.02 & 32.3 \\
\hline Palmitoleic acid & C16:1 & 1.04 & 0.22 & 1.56 & 0.13 & 0.21 & 0.96 & 0.83 \\
\hline \multirow[t]{3}{*}{ Margaric acid } & C17:0 & - & 0.21 & - & - & - & - & - \\
\hline & C17:1 & - & - & 2.38 & 0.73 & 1.11 & 3.21 & 2.34 \\
\hline & C17:3 & - & - & 1.38 & 0.77 & 0.22 & 0.88 & 0.93 \\
\hline Stearic acid & C18:0 & 6.46 & 2.38 & 3.82 & 2.17 & 3.98 & 5.75 & 4.38 \\
\hline Oleic acid & C18:1 & 9.31 & 41.71 & 33.6 & 46.86 & 32.98 & 40.21 & 41.3 \\
\hline Linoleic acid & C18:2 & 53.5 & 29.54 & - & - & - & - & - \\
\hline \multirow[t]{2}{*}{ Linolenic acid } & C18:3 & - & 11.67 & - & - & - & - & - \\
\hline & C19:1 & - & 17.28 & 17.28 & 20.57 & 2.87 & 12.89 & 11.3 \\
\hline Arachidic acid & C20:0 & - & 0.12 & - & - & - & - & - \\
\hline Arachidonic acid & $\mathrm{C} 22: 4$ & - & 0.22 & - & - & - & - & - \\
\hline Behenic acid & $\mathrm{C} 22: 0$ & - & 0.25 & - & - & - & - & - \\
\hline Erucic acid & $\mathrm{C} 22: 1$ & - & 7.09 & - & - & - & - & - \\
\hline Lignoceric acid & $\mathrm{C} 24: 0$ & - & 0.16 & - & - & - & - & - \\
\hline References & & [57] & [87] & & & [88] & & \\
\hline
\end{tabular}

Table 13: Fatty Acid Composition of Different Pleurotus Strain [89]

\begin{tabular}{|c|c|c|c|c|c|c|}
\hline \multicolumn{7}{|c|}{ Fatty acid compositions } \\
\hline P. abalones LGM 39 & 18.43 & 2.61 & 6.50 & 21.37 & 49.43 & 1.68 \\
\hline P. abalones PO 37 & 25.33 & 3.70 & 5.43 & 25.18 & 38.66 & 1.70 \\
\hline P. calyptratusMUCL 28909 & 16.05 & 1.23 & 6.69 & 12.27 & 61.26 & 2.51 \\
\hline P. cystidiosus ATCC 28597 & 16.59 & 1.98 & 3.81 & 36.39 & 38.59 & 2.66 \\
\hline P. cystidiosus ATCC 28597 & 32.17 & 32.1 & 3.72 & 6.92 & 20.49 & 33.26 \\
\hline P. eryngiiCBS 10082 & 15.17 & 0.21 & 5.15 & 46.87 & 30.84 & 1.76 \\
\hline P. eryngii LGM 850404 & 15.79 & 0.42 & 3.87 & 43.97 & 34.92 & 1.04 \\
\hline P. pulmonarius CBS 13385 & 19.61 & 1.37 & 12.94 & 13.37 & 49.31 & 3.41 \\
\hline P. pulmonarius ATCC 34682 & 12.29 & 2.73 & 6.01 & 17.22 & 59.19 & 3.41 \\
\hline P.sajor-caju MUCL 29148 & 22.83 & 1.34 & 14.46 & 13.13 & 45.42 & 2.84 \\
\hline P.sajor-caju LGM 851003 & 25.10 & 1.32 & 11.58 & 12.17 & 46.38 & 3.46 \\
\hline P. sapidus ATCC 29986 & 14.91 & 1.44 & 9.63 & 21.40 & 52.62 & - \\
\hline
\end{tabular}

Note: C 16:0 palmitic acid; C16:1 palmitoleic acid; C18:0 stearic acid; C 18.1, oleic acid; C18,2, linoleic acid. 


\subsection{Soluble Sugar}

Myo-inositol was found in the highest amounts only in $P$. ferulae mushrooms ( 3.69 and $34.31 \mathrm{mg} / \mathrm{g}$ weight) (Table 14). Usually, glucose, mannitol and trehalose were established in several species of Pleurotus. Mannitol and trehalose are the main representatives of alcoholic sugars and oligosaccharides, respectively [77]. The contents vary widely both among species and probably within individual species. This could be seen in $P$. ostreatus, $P$. ferulae, $P$. sajor-caju and $P$. cystidiosus where most of the soluble sugar presences are glucose and mannose. In mushrooms, soluble sugars controlled contributed a sweet or sugary taste. Carbohydrates constitute about one-half of mushroom dry mass. The group comprises various compounds: sugars (monosaccharides, their derivatives and oligosaccharides) and both reserve and construction polysaccharides (glycans).

\subsection{Volatile Compounds}

The aroma of mushrooms came from volatile compound it possessed. In the food nourishment, one of the most important consumer acceptances evaluating dishes is the flavor of the foods itself. Mushrooms contain typical volatile of aromatic compounds. The most important components are terpenes including hydrocarbons formed from isoprene unit, open chain, closed chain, cyclic, saturated and unsaturated fatty acids [91].

Table 15 presented the isolated volatile flavor compounds found in edible mushroom of Pleurotus species were 3-octanone, 1-octen-3-one, 3-octanol, 1octen-3-ol, benzaldehyde, 1-octanol and 2-octen-1-ol. Benzaldehyde was recognized as the major compound in 2 type fruiting bodies of $P$. eryngii. Other studies also reported that 1-octen-3-one were the major volatile absent in $P$. florida, $P$. ostreatus and $P$. Sajor-caju. These compounds obtained from the mushroom species is not very important as nutritional, but only provide aroma, to gives mushrooms dishes a characteristic flavor [69, 92]. Table 16 shows the estimated main volatile compounds of Pleurotus species by the \% Area of volatile compounds in the chromatogram. Two prominent volatile compounds in

Table 14: Soluble Sugar Composition of Pleurotus Species

\begin{tabular}{|c|c|c|c|c|c|c|c|}
\hline \multirow{2}{*}{ Sugar } & \multicolumn{7}{|c|}{ Content (mg/g dry weight) } \\
\cline { 2 - 8 } & $\boldsymbol{P .}$ djamor & $\boldsymbol{P}$. refulae & $\begin{array}{c}\boldsymbol{P} \text {. } \\
\text { nebrodensis }\end{array}$ & $\boldsymbol{P}$. sapidus & $\boldsymbol{P}$. ostreatus & $\boldsymbol{P}$. ferulae & $\begin{array}{c}\boldsymbol{P} \text {. } \\
\text { cystidiosus }\end{array}$ \\
\hline \hline Glucose & 1.47 & 3.39 & 6.85 & 7.25 & 10.6 & 13.2 & 11.6 \\
Mannitol & 3.65 & 10.10 & 9.33 & 9.91 & 3.60 & 31.6 & 24.6 \\
Trehalose & 4.25 & 6.68 & 7.51 & 14.8 & 2.73 & 33.3 & 28.6 \\
Myo-inositol & 9.37 & 20.2 & 23.7 & 31.9 & 1.27 & 34.0 & $\mathrm{Nd}$ \\
Arabitol & & & & & 18.2 & 24.1 & $\mathrm{Nd}$ \\
Total & & & & & & 125 & 64.9 \\
\hline References & {$[52]$} & {$[52]$} & {$[52]$} & {$[52]$} & {$[77]$} & {$[90]$} & {$[77]$} \\
\hline
\end{tabular}

Table 15: Volatile Compounds in the Pleurotus Species

\begin{tabular}{|c|c|c|c|}
\hline \multirow{2}{*}{ Compound } & $\begin{array}{c}\boldsymbol{P} \text {. eryingii } \\
\text { Large fruiting body }\end{array}$ & $\begin{array}{c}\boldsymbol{P} \text {. eryingii } \\
\text { small fruiting body }\end{array}$ & $\begin{array}{c}\boldsymbol{P} \text {. ostreatus using } \mathrm{CCI}_{\mathbf{4}} \\
\text { extraction }\end{array}$ \\
\cline { 2 - 4 } & $\boldsymbol{\mu g} / \mathbf{g}$ fresh wt. & $\boldsymbol{\mu g} / \mathbf{g}$ fresh wt. & $\boldsymbol{\mu} / \mathbf{g}$ fresh wt. \\
\hline \hline 3-octanone & $0.27 \mathrm{~A}$ & $0.29 \mathrm{~A}$ & 136 \\
1-octen-3-one & $0.20 \mathrm{~A}$ & $0.07 \mathrm{~B}$ & 217 \\
3-octanol & $0.10 \mathrm{~B}$ & $0.14 \mathrm{~A}$ & 558 \\
1-octen-3-ol & $0.03 \mathrm{~B}$ & $0.03 \mathrm{~B}$ & 2800 \\
benzaldehyde & $26.75 \mathrm{~A}$ & $15.61 \mathrm{~B}$ & 256 \\
1-octanol & $1.05 \mathrm{~A}$ & $0.83 \mathrm{~A}$ & \\
2-octen-1-ol & $0.70 \mathrm{~A}$ & $0.81 \mathrm{~A}$ & \\
total & $29.10 \mathrm{~A}$ & $17.78 \mathrm{~B}$ & \\
\hline References & & & \\
\hline
\end{tabular}


Table 16: Estimated Main Volatile Compounds of Pleurotus Species Obtained by Comparing GS-MS Library Catalog [94]

\begin{tabular}{|c|c|c|c|}
\hline Volatile compound of $\boldsymbol{P}$. ostreatus & $\mathbf{a} \%$ & Volatiles compounds of $\boldsymbol{P}$. sajor-caju & a\% \\
\hline \hline 1-Dodecanal-lauraldehyde & 1.97 & 2,5-Dimethyloctane & 4-Ethyloctane \\
\hline 1,2-Di(choloroacetoxy) octane & 2.56 & N-octan-3-ol & 3.68 \\
\hline Octadecanoic acid & 1.74 & 2-Methoxythiozole & 3.19 \\
\hline Nonadecanoic acid & 26.28 & Hexadecanoic acid-palmitic acid & 31.61 \\
\hline 2-Nitrocyclooctanone & 5.58 & 3,4-Dimethyldecane & 4.01 \\
\hline 9,12-Octadecadien-1-ol & 24.64 & Octadecanoic acid & 6.12 \\
\hline Cis-Linoleic acid methyl ester & 13.11 & 9-Hexadecenoic acid, 9-hexadecenyl ester & 9.37 \\
\hline Akuammilan-17-ol & 2.04 & 9-Dodecenol & 4.32 \\
\hline Hexadecadienoic acid, methyl ester & 5.66 & 9almitic acid, (2-tetradecyloxy)ethyl ester & 14.92 \\
\hline
\end{tabular}

* a\% Area of volatile compounds in the chromatogram.

$P$. ostreatus are Nonadecanoic acid and 9,12Octadecadien-1-ol with value of $26.28 \%$ and $24.64 \%$ respectively. On the side of $P$. sajor-caju, the highest area percentage of volatile compound is hexadecanoic acid-palmitic acid of $31.61 \%$.

\section{CONCLUSIONS}

The mushrooms belong to Pleurotus spp. are highly diversified group and distributed world-wide. Almost all mushrooms belong to this species are edible and used in different culture as potential source of food and medicines. They are rich of large amount of essential nutrients such as carbohydrates, proteins, vitamins, amino acids, fiber, in organic elements, lipid and volatile active compounds. Thus, they are considered as one of the richest well-balanced source for human nutrition and widely human food and nutraceutical industries. In addition they are able to grow on almost all agro-industrial waste based on their high ability to degrade lignocellulosic material. This make them more attractive component of any waste to wealth programs. In spite of many research done in identification, cultivation, and nutritional profiling of Pleurotus spp., studies are required to integrate the knowledge between the mushroom species, ability to degrade different types of lignocellulosic wastes, and the nutritional value of the grown mushroom. This will help for sure to increase our knowledge and awareness to improve the current application of this type of healthy food in both fresh and processed form.

\section{REFERENCES}

[1] Smith JE, Rowan NJ, Sullivan R. Medicinal Mushrooms: Their therapeutic properties and current medical usage with special emphasis on cancer treatments USA: University of Strathclyde; 2002.

[2] El-Enshasy HA, Hatti-Kaul R. Mushroom Immunomodulators: unique molecules with unlimited applications. Trends Biotechnol 2013; 31(12): 668-77. http://dx.doi.org/0.1016/j.tibtech.2013.09.003

[3] Soltani M, Kamyab H, El-Enshasy HA. Molecular weight (Mw) and Monosaccharide composition (MC): Two major factors affecting the therapeutic action of polysaccharides extracted from Cordyceps sinensis. J Pure Appl Microbiol 2013; 7(3): 1601-13.

[4] Sarmidi MR, El Enshasy HA. Biotechnology for wellness industry: Concepts and biofactories. Int J Biotechnol Well Ind 2012; 1(1): 3-29.

[5] Deepalakshmi K, Mirunalini S. Pleurotus ostreatus: an oyster mushroom with nutritional and medicinal properties. J Biochem Tech 2014; 5(2): 718-26.

[6] Ozturk M, Tel-Cayan G, Muhammad A, Terzioglu P, Emin Duru M. Mushrooms: A source of exciting bioactvie. Studies in Natural Products Chem 2015; 45(1): 363-456. http://dx.doi.org/10.1016/B978-0-444-63473-3.00010-1

[7] Wang S, Bao L, Zhao F, et al. Isolation, identification, and bioactivity of monoterpenoids and sesquiterpernoids from the mycelia of edibl mushroom Pleurotus cornucopiae. J Agr Food Chem 2013; 61(21): 5122-9.

[8] Atri NS, Sharma SK. Qualitative estimation of cellulase and lignin modifying enzymes in five wild fungal species collected from Northern West India. Acad J Plant Sci 2012; 5(1): 23-7. http://dx.doi.org/10.5829/idosi.ajps.2012.5.1.235

[9] El-Enshasy HA, Elsayed EA, Aziz R, Wadaan MA Mushrooms and Truffles: Historical biofactories for complementary medicine in Africa and in the Middle East. Evidence-Based Complementary and Alternative Medicine 2013; 10 (2013: 620451) http://dx.doi.org/10.1155/2013/620451

[10] El Enshasy H, Daba A, El Demellawy M, Ibrahim A, El Sayed S, El Badry I. Bioprocess development for large scale 
production of anticancer exo-polysaccharide by Pleurotus ostreatus in submerged culture. J Appl Sci 2010; 10: 2523-9. http://dx.doi.org/10.3923/jas.2010.2523.2529

[11] Maftoun P, Malek R, Abbas M, Aziz R, El Enshasy H. Bioprocess for semi-industrial production of immunomodulator polysaccharide Pleuran by Pleurotus ostreatus in submerged culture. J Sci and Industr Res 2013; 72: $655-62$.

[12] Kong W-S. Mushroom growers handbook 1: Oyster mushroom cultivation 2004; 1: 54-61. http://mushroomtime.org/wp-content/uploads/2014/06/02Mushroom-Growers-Handbook-1-Oyster-MushroomCultivation-MUSHWORLD.pdf

[13] Musieba F, Okoth S, Mibey RK. First record of the occurrence of Pleurotus citrinopileatus singer on new hosts in Kenya. Agric Biol J N Am 2011; 2(9): 1304-9.

http://dx.doi.org/10.5251/abjna.2011.2.9.1304.1309

[14] Gargano ML, Venturella G, Zervakis GI. Pleurotus nebrodensis: A very special mushroom. Sharjah, U.A.E.: Bentham Science Publishers; 2013.

[15] Pramanik M, Chakraborty I, Mondal S, Islam SS. Structural analysis of a water-soluble glucan (Fr.I) of an edible mushroom, Pleurotus sajor-caju. Carbohyd Res 2007; 342(17): 2670-5.

http://dx.doi.org/10.1016/j.carres.2007.08.012

[16] Dey B, Bhunia SK, Maity KK, et al. Chemical analysis of an immunoenhancing water-soluble polysaccharide of an edible mushroom, Pleurotus florida blue variant. Carbohyd Res 2010; 345(18): 2736-41. http://dx.doi.org/10.1016/j.carres.2010.09.032

[17] Rout D, Mondal S, Chakraborty I, Pramanik M, Islam SS. Chemical analysis of a new $(1 \rightarrow 3)-,(1 \rightarrow 6)$-branched glucan from an edible mushroom, Pleurotus florida. Carbohyd Res 2005; 340(16): 2533-9. http://dx.doi.org/10.1016/j.carres.2005.08.006

[18] Zervakis GI, Bekiaris G, Tarantilis PA, Pappas CS. Rapid strain classification and taxa delimitation within the edible mushroom genus Pleurotus through the use of diffuse reflectance infrared Fourier transform (DRIFT) spectroscopy. British Mycological Society, Promoting Fungal Sciences (BMS) 2012; 116(6): 715-28.

http://dx.doi.org/10.1016/j.funbio.2012.04.006

[19] Otieno OD, Onyango C, Onguso JM, et al. Genetic Diversity of Kenyan Native Oyster Mushroom (Pleurotus spp.). Mycologia 2015; 107(2): 32-8.

http://dx.doi.org/10.3852/13-186

[20] Alam N, Lee JS, Lee TS. Mycelial growth conditions and molecular phylogenetic relationships of Pleurotus ostreatus World Appl Sci J 2010; 9(8): 928-37.

[21] Zervakis G, Sourdis J, Balis C. Genetic variability and systematics of eleven Pleurotus species based on isozyme analysis. Mycol Res 1994; 98(3): 329-41.

\section{http://dx.doi.org/10.1016/S0953-7562(09)80461-9}

[22] Ro H-S, Kim SS, Ryu JS, Jeon C-O, Lee TS, Lee H-S. Comparative studies on the diversity of the edible mushroom Pleurotus eryngii: ITS sequence analysis, RAPD fingerprinting, and physiological characteristics. Mycol Res 2007; 111(6): 710-5.

http://dx.doi.org/10.1016/j.mycres.2007.03.016

[23] Rout D, Mondal S, Chakraborty I, Islam SS. The structure of a polysaccharide from Fraction-II of an edible mushroom, Pleurotus florida. Carbohyd Res 2006; 341(8): 995-1002. http://dx.doi.org/10.1016/j.carres.2006.02.026

[24] Estrada AER, Jimenez-Gasco MdM, Royse DJ. Pleurotus eryngii species complex: Sequence analysis and phylogeny based on partial EF1[alpha] and RPB2 genes. Fungal Biol 2010; 114(5-6): 421-8. http://dx.doi.org/0.1016/j.funbio.2010.03.003
[25] Bao D, Ishihara $\mathrm{H}$, Mori N, Kitamoto $\mathrm{Y}$. Phylogenetic analysis of oyster mushrooms (Pleurotus spp.) based on restriction fragment length polymorphisms of the $5^{\prime}$ portion of $26 \mathrm{~S}$ rDNA. J of Wood Sci 2004; 50(2): 169-76.

http://dx.doi.org/10.1007/s10086-003-0539-5

[26] Zervakis G, Balis C. A pluralistic approach in the study of Pleurotus species with emphasis on compatibility and physiology of the European morphotaxa. Mycol Res 1996; 100(6): 717-31.

http://dx.doi.org/10.1016/S0953-7562(96)80205-X

[27] Bao D, Kinugasa S, Kitamoto $Y$. The biological species of oyster mushrooms (Pleurotus spp.) from Asia based on mating compatibility tests. J Wood Sci 2004; 50(2): 162-8. http://dx.doi.org/10.1007/s10086-003-0540-z

[28] Urbanelli S, Della Rosa V, Punelli F, et al. DNA-fingerprinting (AFLP and RFLP) for genotypic identification in species of the Pleurotus eryngii complex. Appl Microbiol Biotechnol 2007; 74(3): 592-600.

http://dx.doi.org/10.1007/s00253-006-0684-z

[29] Vilgalys $R$, Lin sun B. Ancient and recent patterns of geographic speciation in the oystermushroom Pleurotus revealed by phylogenetic analysis of ribosomal DNA sequences. Proc Nation Acad Sci 1994; 91(10): 4599-603.

[30] Bunyard BA, Chaichuchote S, Nicholson MS, Royse DJ. Ribosomal DNA analysis for resolution of genotypic classes of Pleurotus. Mycol Res 1996; 100(2): 143-50. http://dx.doi.org/10.1016/S0953-7562(96)80112-2

[31] Ravash R, Shiran B, Alavi A-A, Bayat F, Rajaee S, Zervakis G. Genetic variability and molecular phylogeny of Pleurotus eryngii species-complex isolates from Iran, and notes on the systematics of Asiatic populations. Mycol Prog 2010; 9(2): 181-94.

http://dx.doi.org/10.1007/s11557-009-0624-2

[32] Benkortbi O, Hanini S, Bentahar F. Batch kinetics and modelling of Pleuromutilin production by Pleurotus mutilis. Biochem Eng J 2007; 36(1): 14-8. http://dx.doi.org/10.1016/j.bej.2006.06.015

[33] Gupta B, Niranjan Reddy B, Kotasthane A. Molecular characterization and mating type analysis of oyster mushroom (Pleurotus spp.) using single basidiospores for strain improvement. World J Microbiol Biotechnol 2010; 27(1): $1-9$.

http://dx.doi.org/10.1007/s11274-010-0419-2

[34] James TY, Liou S-R, Vilgalys $R$. The genetic structure and diversity of the $A$ and $B$ mating-type genes from the tropical oyster mushroom, Pleurotus djamor. Fungal Gen and Biol 2004; 41(8): 813-25. http://dx.doi.org/10.1016/j.fgb.2004.04.005

[35] Saha A, Acharya S, Roy A. Antioxidant level of wild edible mushroom: Pleurotus djamor (Fr.) Boedjin. J Agric Technol 2012; 8: 1343-51.

[36] Isikhuemhen OS, Moncalvo J-M, Nerud F, Vilgalys R. Mating compatibility and phylogeography in Pleurotus tuberregium. Mycol Res 2000; 104(6): 732-7. http://dx.doi.org/10.1017/S0953756299001926

[37] Shnyreva A, Shtaer O. Differentiation of closely related oyster fungi Pleurotus pulmonarius and $P$. ostreatus by mating and molecular markers. Russ J Genet 2006; 42(5): 539-45. http://dx.doi.org/10.1134/s1022795406050115

[38] Liu Y-T, Sun J, Luo Z-Y, et al. Chemical composition of five wild edible mushrooms collected from Southwest China and their antihyperglycemic and antioxidant activity. Food and Chem Toxicol 2012; 50(5): 1238-44

http://dx.doi.org/10.1016/j.fct.2012.01.023

[39] Kalogeropoulos N, Yanni AE, Koutrotsios G, Aloupi M. Bioactive microconstituents and antioxidant properties of wild edible mushrooms from the island of Lesvos, Greece. Food and Chem Toxicol 2013; 55(1): 378-85. http://dx.doi.org/10.1016/j.fct.2013.01.010 
[40] Silva S, Martins S, Karmali A, Rosa E. Production, purification and characterisation of polysaccharides from Pleurotus ostreatus with antitumour activity. $\mathrm{J}$ of the Sci of Food and Agric 2012; 92(9): 1826-32.

http://dx.doi.org/10.1002/jsfa.5560

[41] Mattila P, Lampi AM, Ronkainen R, Toivo J, Piironen V. Sterols and vitamin D2 contents in some wild and cultivated mushrooms. Food Chem 2002; 76(3): 293-8. http://dx.doi.org/10.1016/S0308-8146(01)00275-8

[42] Manzi P, Gambelli L, Marconi S, Vivanti V, Pizzoferato L. Nutrients in edible mushrooms: an interspecies comparatively study. Food Chem 1999; 65(4): 477-82. http://dx.doi.org/10.1016/S0308-8146(98)00212-X

[43] Khan MA, Tania M. Nutritional and medicinal importance of Pleurotus mushrooms: An overview. Food Rev Int 2012; 28(3): 313-29.

http://dx.doi.org/10.1080/87559129.2011.637267

[44] Chye FY, Wong JY, Lee JS. Nutritional quality and antioxidant activity of selected edible wild mushrooms. Food Sci and Technol Int 2008; 14(4): 375-84. http://dx.doi.org/10.1177/1082013208097445

[45] Li X, Feng T, Zhou F, et al. Effects of drying methods on the tasty compounds of Pleurotus eryngii. Food Chem 2015; 166(1): 358-64.

http://dx.doi.org/10.1016/j.foodchem.2014.06.049

[46] Bano Z, Bhagya S, Srinivasan KS. Essential amino acid composition and proximate analysis of the mushroom Pleurotus osterious and $P$. florida. Mushroom Newsletter of the Tropics 1981; 1(3): 6-10.

[47] Bisaria R, Madan M. Mushrooms: potential protein source from cellulosic residues. Enzyme Microb Technol 1983; 5(4): 251-9. http://dx.doi.org/10.1016/0141-0229(83)90073-X

[48] Cuptapun Y, Hengsawadi D, Mesomya W, Yaieiam S. Quality and quantity of protein in certain kinds of edible mushroom in Thailand. Kasetsart J Nat Sci 2010; 44: 664-70.

[49] Crisan EV, Sands A. Nutritional value: in the biology and cultivation of edible mushrooms. In: Chang ST, Hayes Wa, editors. New York: Academic Press; 1978. p. 137-68.

[50] Chirinang $\mathrm{P}$, Intarapiche K-O. Amino acids and antioxidant properties of the oyster mushrooms, Pleurotus ostreatus and Pleurotus sajor-caju. Science Asia 2009; 35: 326-31. http://dx.doi.org/10.2306/scienceasia1513-1874.2009.35.326

[51] Chang ST, Lau OW, Cho KY. The cultivation and nutritional value of Pleurotus sajor-caju. Eur J Appl Microbiol Biotechnol 1981; 12(1): 58-62. http://dx.doi.org/10.1007/BF00508120

[52] Guo LQ, Lin JY, Lin JF. Non-volatile components of several novel species of edible fungi in China. Food Chem 2007; 100(2): 643-9.

http://dx.doi.org/10.1016/j.foodchem.2005.09.087

[53] Wani BA, Bodha RH, Wani AH. Nutritional and medicinal importance of mushrooms. J Med Plants Res 2010; 4(24): 2598-604.

http://dx.doi.org/10.5897/JMPR09.565

[54] Beluhan S, Ranogajec A. Chemical composition and nonvolatile components of Croatian wild edible mushrooms. Food Chem 2011; 124(3): 1076-82.

http://dx.doi.org/10.1016/j.foodchem.2010.07.081

[55] Fernandes Â, Barros L, Martins A, Herbert P, Ferreira ICFR. Nutritional characterisation of Pleurotus ostreatus (Jacq. ex Fr.) P. Kumm. produced using paper scraps as substrate. Food Chemistry 2015; 169(1): 396-400. http://dx.doi.org/10.1016/j.foodchem.2014.08.027

[56] Cui F, Li Y, Yang Y, Sun W, Wu D, Ping L. Changes in chemical components and cytotoxicity at different maturity stages of Pleurotus eryngii fruiting body. J Agric and Food Chem 2014; 62(52): 12631-40.

http://dx.doi.org/10.1021/jf5048354
[57] Mukhopadhyay R, Guha AK. A comprehensive analysis of the nutritional quality of edible mushroom Pleurotus sajorcaju grown in deproteinized whey medium. LWT - Food Sci and Technol 2015; 61(2): 339-45.

http://dx.doi.org/10.1016/j.Iwt.2014.12.055

[58] Parashare V, Pal S, Bhandari A. Antimicrobial and nutritional studies on Agaricus bisporus and Pleurotus ostreatus. Acta Biologica Indica 2013; 2(1): 310-5.

[59] Egwin EC, Elem RC, Egwuche RU. Proximate composition, phytochemical screening and antioxidant activity of ten selected wild edible Nigerian mushrooms. Am J of Food and Nut 1(2): 89-94

http://dx.doi.org/10.5251/ajfn.2011.1.2.89.94

[60] Cohen N, Cohen J, Asatiani M, et al. Chemical composition and nutritional and medicinal value of fruit bodies and submerged cultured mycelia of culinary-medicinal higher Basidiomycetes mushrooms. Int J of Med Mushrooms 2014; 16(3): 273-91.

http://dx.doi.org/10.1615/IntJMedMushr.v16.i3.80

[61] Reis FS, Barros L, Martins A, Ferreira ICFR. Chemical composition and nutritional value of the most widely appreciated cultivated mushrooms: An inter-species comparative study. Food and Chem Toxicol 2012; 50(2): 191-7.

http://dx.doi.org/10.1016/j.fct.2011.10.056

[62] Akyüz M, Kirbağ S. Nutritive value of wild edible and cultured mushrooms. Turkish J of Biol 2010; 34: 97-102. http://dx.doi.org/10.1016/j.fct.2011.10.056

[63] Ahmed M, Abdullah N, Ahmed KU, Bhuyan MHMB. Yield and nutritional composition of oyster mushroom strains newly introduced in Bangladesh. Pesquisa Agropecuária Brasileira 2013; 48(2): 197-202. http://dx.doi.org/10.1590/S0100-204X2013000200010

[64] Patil AS, Ahmed SA, Telang SM, Baig MMV-. The nutritional value of Pleurotus ostreatus (Jacq: Fr) Kumm. cultivated on diffrent lignocellulosic agrowastes. Innovation Romanian Food Biotechnol 2010; 7: 66-76.

[65] Colak A, Özlem F, Sesli E. Nutritional composition of some wild edible mushrooms. Turkish J Biochem 2009; 34(1): 2531.

[66] Pushpa H, Purushothama KB. Nutritional analysis of wild and cultivated edible medicinal mushrooms. World $\mathrm{J}$ of dairy and Food Sci 2010; 5(1): 140-4.

[67] Chang ST, Buswell JA. Mushroom nutriceuticals. World J of Microbiol and Biotechnol 1996; 12(5): 473-6. http://dx.doi.org/10.1007/BF00419460

[68] Mau JL, Ching Lin H, Tsun Ma J, fu Song S. Non-volatile taste components of several speciality mushrooms. Food Chem 2001; 73(4): 461-6. http://dx.doi.org/10.1016/S0308-8146(00)00330-7

[69] Mau J, L, Lin YP, Chen PT, Wu Y, H, Torng P. Flavor compounds in king osyster mushrooms Pleurotus eryngii. $J$ Agric Food Chem 1998; 46(11): 4587-91. http://dx.doi.org/10.1021/jf980508+

[70] Kalač P. A review of chemical composition and nutritional value of wild-growing and cultivated mushrooms. J of Sci of Food and Agric 2013; 93(2): 209-18. http://dx.doi.org/10.1002/jsfa.5960

[71] Hossain MS, Alam N, Amin SR, Basunia MA, Rahman A. Essential fatty acid contents of Pleurotus ostreatus, Ganoderma lucidum and Agaricus bisporus. Bangladesh J of Mushroom 2007; 1(1): 1-7.

[72] Othman RA, Moghadasian MH, Jones PJ. Cholesterollowering effects of oat $\beta$-glucan Nut Rev 2011; 69: 299-309. http://dx.doi.org/10.1111/j.1753-4887.2011.00401.x.

[73] Ruszova E, Pavek S, Hajkova V, et al. Photoprotective effects of glucomannan isolated from Candida utilis. Carbohydr Res 2008; 343(3): 501-11. http://dx.doi.org/10.1016/j.carres.2007.11.010 
[74] El Enshasy HA, Maftoun P, Abd Malek R. Pleuran: Immunomodulotor Polysaccharide from Pleurotus ostreatus, Structure, Production and Application. In: Andres S, Baumann N, editors. Mushrooms: Types, Properties and Nutrition. NY, USA: Nova publisher; 2012. p. 153-72.

[75] Elefherios E, Vassilis MG, C. I. The potential use of mushrooms $\beta$-glucans in the food industry. Int $\mathrm{J}$ Biotechnol Well Ind 2014; 3: 15-8.

[76] Mattila P, Salo-Väänänen P, Könkö K, Aro H, Jalava T. Basic composition and amino acid contents of mushrooms cultivated in Finland. J of Agric and Food Chem 2002; 50(22): 6419-22. http://dx.doi.org/10.1021/jf020608m

[77] Yang JH, Lin HC, Mau JL. Non-volatile taste components of several commercial mushrooms. Food Chem 2001; 72(1): 465-71.

http://dx.doi.org/10.1016/S0308-8146(00)00262-4

[78] Li GSF, Chang ST. The nucleic acid contentnof some edible mushrooms. Eur J Appl Microbiol Biotechnol 1982; 15(1): 237-40. http://dx.doi.org/10.1007/BF00499963

[79] Tabata T, Ogura T. Proximate and free amino acid composition during development of fruit body of Kuroawabitake (Pleurotus abalones Han, Chen et Cheng). Food Sci Technol Res 2004; 10(2): 32-4.

[80] Alam N, Amin R, Khan A, et al. Nutritional analysis of cultivated mushrooms in Bangladesh-Pleurotus ostreatus, Pleurotus sajor-caju, Pleurotus florida and Calocybe indica. Mycobiol 2008; 36(4): 228-32. http://dx.doi.org/10.4489/MYCO.2008.36.4.228

[81] Breene WM. Nutritional and medicinal value of speciality mushrooms. J Food Protection 1990; 53(17): 883-99.

[82] Mattila $\mathrm{P}$, Konko $\mathrm{K}$, Eurola $\mathrm{M}$, et al. Contents of vitamins, mineral elements and some phenolic compunds in the cultivated muhrooms. J Agric Food Chem 2001; 49(5): 23438.

http://dx.doi.org/10.1021/jf001525d

[83] Teichmnn A, Dutta PC, Staffas A, Jagerstad M. Sterol and vitamin D2 concentrations in cultivated and wild grown mushrooms Effects of UV irradation. LWT Food Sci and Technol 2007; 40(5): 815-22. http://dx.doi.org/10.1016/j.Iwt.2006.04.003

[84] Kurtzman $\mathrm{RH}$. Mushrooms: source for modern western medicine. Micologia Aplicada Int 2005; 17(2): 21-33.

[85] Furlani RPZ, Godoy HT. Vitamins B1 and B2 contents in cultivated mushrooms. Food Chemistry 2008; 106(2) : 816-9. http://dx.doi.org/10.1016/j.foodchem.2007.06.007
[86] Dundar A, Acay H, Yildiz A. Effect of using different lignocellulosic wastes for cultivation of Pleurotus ostreatus (Jacq) P. Kumm. On mushroom yiled, chemical composition and nutritional value. Afr J Biotechnol 2009; 8(4): 662-6.

[87] Kayode RMO, Olakulehin TF, Adedeji BS, Ahmed O, Aliyu $\mathrm{TH}$, Badmos AHA. Evaluation of amino acid and fatty acid profiles of commercially cultivated oyster mushroom (Pleurotus sajor-caju) grown on gmelina wood waste. Nigerian Food J 2015; In Press.

http://dx.doi.org/10.1016/j.nifoj.2015.04.001

[88] Atri NS, Sharma SK, Joshi R, Gulati A, Gulati A. Nutritional and Neutraceutical Composition of Five Wild CulinaryMedicinal Species of Genus Pleurotus (Higher Basidiomycetes) from Northwest India. Int J Med Mushrooms 2013; 15(1): 49-56.

http://dx.doi.org/10.1615/IntJMedMushr.v15.i1.60

[89] Dimou D, M, Georgala A, Komaitis M, Aggelis G. Mycelial fatty acid composition of Pleurotus spp and its application in the intrageneric differentiation. Mycol Res 2002; 106(8): 98529.

http://dx.doi.org/10.1017/S0953756202006184

[90] Tsai SY, Huang SJ, Lo SH, Wu tP, Lian PY, Mau JL. Flavour components and antioxidant properties of several cultivated mushrooms. Food Chem 2009; 113(2): 578-84. http://dx.doi.org/10.1016/j.foodchem.2008.08.034

[91] Jong SC, Birmingan JM. Mushrooms a source of natural flavor and aroma compounds. In: Chang ST, Buswell JA, Chiu SW, editors. Mushroom biology and mushroom products, proceeding of the first international conference. Hong Kong: The Chinese University of Hong Kong; 1993. p. 345-65.

[92] Jung ST, Hong JS. Volatile compounds of oyster mushrooms (Pleurotus spp) cultivated in Korea. Korean J Mycol 1991; 19(1): 299-305.

[93] Beltran-Garcia M, Estarron-Espinosa M, Ogura T. Volatile compounds secreted by the oyster mushroom (Pleurotus ostreatus) and their antibactericial activities. J agric Food Chem 1997; 45(10): 4049-52. http:///dx.doi.org/10.1021/jf960876

[94] Çağlarırmak N. The nutrients of exotic mushrooms (Lentinula edodes and Pleurotus species) and an estimated approach to the volatile compounds. Food Chem 2007; 105(3): 118894.

http://dx.doi.org/10.1016/j.foodchem.2007.02.021

\section{DOI: http://dx.doi.org/10.6000/1927-3037.2015.04.02.4}

(C) 2015 Maftoun et al.; Licensee Lifescience Global.

This is an open access article licensed under the terms of the Creative Commons Attribution Non-Commercial License (http://creativecommons.org/licenses/by-nc/3.0/) which permits unrestricted, non-commercial use, distribution and reproduction in any medium, provided the work is properly cited. 